\title{
Thermal Analysis on Radial Flux Permanent Magnet Generator (PMG) using Finite Element Method
}

\author{
Pudji Irasari ${ }^{1}$, Hilman Syaeful A ${ }^{2}$, and Muhammad Kasim ${ }^{1}$
}

\begin{abstract}
The main source of heat in the permanent magnet generator (PMG) is the total losses which f come from winding losses, core losses and rotational losses. Total heat arising from such these losses must be properly distributed and maintained so as not to exceed the maximum allowable temperature to prevent damage to insulation on the winding and demagnetization on the permanent magnet machines. In this research, we consider thermal analysis which is occurred on the radial flux PMG by using finite element method to determine the extent to which the heat generated can be properly distributed. The simulation results show that there are no points of heat concentration or hot spot. The simulation maximum temperatures of the permanent magnet and the winding are $39.1^{\circ} \mathrm{C}$ and $72.5^{\circ} \mathrm{C}$ respectively while the experimental maximum temperature of the winding is $62^{\circ} \mathrm{C}$.
\end{abstract}

Keywords - generator, permanent magnet, radial flux, temperature, finite element methode

Abstrak-Sumber utama panas dalam generator magnet permanen (GMP) adalah rugi-rugi yang terdiri dari rugi lilitan, rugi inti dan rugi rotasional. Panas total yang timbul dari rugi-rugi tersebut, harus terdistribusi secara merata dan dijaga supaya tidak melebihi temperatur maksimum yang diizinkan untuk mencegah kerusakan isolator pada lilitan dan demagnetisasi pada mesin magnet permanen. Dalam penelitian ini telah dilakukan analisis termal pada GMP fluks radial menggunakan metoda elemen hingga untuk mengetahui sejauh mana panas yang ditimbulkan dapat terdistribusi secara merata. Hasil simulasi menunjukkan bahwa tidak terjadi titik konsentrasi panas atau hotspot dalam generator. Temperatur maksimum magnet dan lilitan hasil simulasi adalah $39.1^{\circ} \mathrm{C}$ dan $72.5^{\circ} \mathrm{C}$ sedangkan temperatur maksimum hasil eksperimen pada lilitan adalah $62^{\circ} \mathrm{C}$.

Kata Kunci-generator, magnet permanen, fluks radial, temperatur, metoda elemen hingga

\section{INTRODUCTION}

$\mathrm{T}$ emperature rise is caused by the operation of rotating machines is merely an unavoidably natural phenomenon. Related to the temperature rise problem, for a designer an important thing that needs to be considered is how to distribute and reduce the heat so that overheating will not occur. A design analysis therefore focusing on the thermal aspects becomes very important to be ignored in which it provides the existency a certain requirement in which thermal condition must be maintained within the permitted operational limits. An analysis upon temperature distribution is highly necessary to ensure there is no heat concentration point or hotspot that might cause damage to the isolator on the winding or demagnetization on the permanent magnet $[1,2]$.

The method for thermal analysis is basically divided into two, i.e. analytical lumped-circuit (thermal circuit) and numerical method. The method of analytical approach has its own advantage on the faster speed of its computation; nevertheless its circuit modeling demands higher accuracy in order that distribution path for the heat to transfer can be precisely determined.

Pudji Irasari is with Department of Research Center for Electrical Power and Mechatronics, Indonesian Institute of Sciences, Bandung, 40135, Indonesia. E-mail: pudj002@lipi.go.id

Hilman Syaeful A, and Muhammad Kasim are with Department of Technical Implementation Unit for Instrumentation Development, Indonesian Institute of Sciences, Bandung, 40135, Indonesia.
The method of numerical analysis holds its own advantage due to its capability in modeling all geometrical objects. However, it takes longer time in both establishing the model and running the computation.

Two types of numerical analyses are currently in existence, i.e. finite-element analysis (FEA) and computational fluid dynamics (CFD). CFD is more advantageous because once it is used it can predict the flow in a complicated area, e.g. around the end winding of a motor/generator. On the other hand, FEA can only be utilized for modeling conduction heat transfer on solid components [3]. A thermal analysis on electric machine (motor and generator) using finite element method has been conducted by some research.

Mahadi studied linear generator for automotive and stand-alone (standby or remote) generator applications. The effect of heat (generated from combustion engine, current carrying conductors and friction) on the performance of $\mathrm{NdFeB}$ magnet was examined with and without cooling fins [4]. In [5], heat transfer of 600W and $60 \mathrm{~kW}$ switch reluctance motors (SRMs) was investigated. The heat transfer mechanism of $600 \mathrm{~W}$ SRM was done by natural convection; while for $60 \mathrm{~kW}$ SRM the analysis was carried out using copper pipe with water as a cooling system. A $30 \mathrm{~kW}$ solid rotor line-start PMSM with new structure was developed and analyzed in [6]. The study was focused on thermal field of the motor and influences of loads and stray loss on rotor temperature.

This paper considers the thermal analysis on a radial flux permanent magnet generator using finite element 
method in which the main sources of heat are originated from copper losses, core losses and rotational losses.

\section{A. Parameters of Generator}

Principally the analyzed generator could be applied on not only in a wind turbine but also in a micro hydro turbine. Isometric display of the prototype of analyzed generator is depicted in Figure 1, whilst its parameters are presented in Table 1.

\section{B. Heat Source of Generator}

In a PMG, the heat is produced by total losses which comes from copper or winding losses $\left(P_{c u}\right)$, core losses $\left(P_{\text {core }}\right)$ and rotational losses $\left(P_{\text {rot }}\right)$. Those losses are then dissipated to all parts of the machine. At the generator, winding/copper losses, $P_{c u}$ are generated due to resistances of the coil or winding that generates heat effects as the conversion of electric energy [7]. Winding losses can be mentioned using the following equation [8]:

$$
P_{c u}=m R_{a} I^{2}
$$

where $m=$ phase number $=3, R_{a}=$ winding resistance per phase $=3.39 \Omega$, and $I=$ phase current $=3.795 \mathrm{~A}$.

Analyses on the core and rotational losses refer to [7] because they both have the same generator structures. Core losses, $P_{\text {core }}$ are the sum of hysteresis loss and eddy current loss. Core losses can be represented by the following equation:

$P_{\text {core }}=C_{h} f B_{p}{ }^{a+b B_{p}}+C_{e} f^{2} B_{p}{ }^{2}$

where $C_{h}=$ coefficient of hysteresis loss $=0.0025, C_{e}=$ coefficient of eddy current loss $=7.9365 \cdot 10^{-5}, a$ and $b$ are constants which depend upon the material of the stator (soft magnetic/silicon steel), with $a=1.8317$, and $b=-$ 0.0035. $f=$ frequency $=50 \mathrm{~Hz}$, and $B_{p}$ is sinusoidal peak of the flux density $=1.7 \mathrm{~T}$. Rotational losses $P_{\text {rot }}$ consist of friction and windage losses, the rotational losses can be formulated as

$$
P_{\text {rot }}=P_{\text {fric }}+P_{\text {wind }}
$$

Friction loss is computed using equation:

$$
P_{\text {fric }}=k_{f b} W_{r} n \cdot 10^{-3}
$$

where $k_{f b}$ is the constant of bearing friction with the approximation of $1-3, W_{r}=$ weight of the rotor $=13.34$ $\mathrm{kg}$ and $n=300 \mathrm{rpm}$. Meanwhile, wind losses $P_{\text {wind }}$ are computed using equation:

$$
P_{\text {wind }}=2 D_{r}{ }^{3} L_{e n} \cdot 10^{-6}
$$

where $D_{\mathrm{r}}=$ outer diameter of the rotor $=0.0728 \mathrm{~m}$ dan $L_{e n}=$ length of stator lamination $=0.103 \mathrm{~m}$.

\section{Heat Transfer Mechanism}

Heat transfer mechanism inside the generator is shown in Figure 2. The source of heat in generator is produced from the windings located at stator's lamination, from which the heat is then dissipated to all parts of the machine following the pattern of radial heat flow or in the same direction as the generator radial axis and circumpherential heat flow or upright to the generator radial axis.

For a 2-dimension thermal analysis, axial heat flow, which goes towards the same direction as the axis of generator shaft, can be ignored [9]. Data of material characteristics of the generator components associated with thermal analysis can be seen in Table 2 [10].

In general the equation for heat transfer is based on the principle of energy conservation postulating that the network generated equals to the sum of heat produced and energy alteration stored in the system $[4,9,11]$. Mathematically it can be written as follows:

$$
\bar{\nabla} q=Q-\frac{\partial e}{\partial t}
$$

where $q$ is the heat conduction, $Q$ is the heat generated in the system, $\delta e / \delta t$ the change in internal energy. $q$ is derived from Fourier law as heat conduction, namely: $q=-k \bar{\nabla} T$

Therefore, heat transfer on a solid material can be stated in a partial differential equation as follows [4]:

$$
\bar{\nabla}(k \bar{\nabla} T)+Q-\rho C_{p} \frac{\partial T}{\partial t}=0
$$

where $k$ is thermal conductivity, $C_{p}$ is specific heat capacity, $\rho$ is density, $Q$ is rate of the heat which is generated per volume, and $T$ is distribution of the predetermined temperature.

In addition to conduction, heat can be transferred through convection and radiation. Computation of convection heat transfer is more complicated due to involvement of fluid movement and conductive heat. Newton gives a theory that heat transfers that passing thru a certain area is in accordance with the temperature difference of solid fluid. Temperature difference normally occurs through fluid borders located close to the solid surface. The Newton equation can be stated as follows $[4,11]$ :

$Q_{c}=h_{c} A\left(T-T_{A}\right)$

where $h_{c}$ is coefficient of the convection heat transfer, $A$ is area of the heat transfer, and $T_{A}$ is room temperature.

For natural convection, coefficient of the convection from the air is approximately between $6-30 \mathrm{~W} / \mathrm{m}^{2}{ }^{2}{ }^{0} \mathrm{C}$ and for force convection, it is around $30-300 \mathrm{~W} / \mathrm{m}^{2}{ }^{0} \mathrm{C}$ [12] In this research the average coefficient of the convection is $18 \mathrm{~W} / \mathrm{m}^{2}{ }^{0} \mathrm{C}$ because the process of convection heat transfer takes place naturally. For heat transfer by radiation, it occurs from or to the surface surrounded by parallel air with convection between the air and surface. Therefore, the total heat transfer is determined by adding the contribution of those two heat transfer mechanisms. Heat transfer by radiation can be computed using following equation $[4,11]$ :

$Q_{r}=\varepsilon \sigma_{t} A\left(T^{4}-T_{A}^{4}\right)$

From the equation above, coefficient of the radiation heat transfer, $h_{r}$, can be determined as follows:

$h_{r}=\frac{\varepsilon \sigma_{t}\left(T^{4}-T_{A}\right)}{\left(T-T_{A}\right)}$

As the result, the total of heat losses in the generator due to convection and radiation, $Q_{c r}$ is as follows:

$Q_{c r}=\left(h_{c}+h_{r}\right) A\left(T-T_{A}\right)$

During the simulation using finite element method, heat transfer effects caused by radiation is simply ignored due to the high emissions of copper material and silicon steel inside the stator generator, which respectively are 0.63 and 0.7 [4]. 


\section{METHOD}

\section{A. Finite Element Method}

Simulation and analysis of temperature distribution on the PMG is carried out using FEMM 4.2. one of finiteelement-method-based tools. This method is able to give the approximation of unknown values on some discrete points of a continuum by dividing the continuum into smaller elements interconnected to each other at a certain common point of two or more elements (nodal points or nodes) with limited number (finite element) from a simpler geometry than the previous continuum.

The advantage of breaking the domain down into a number of small elements is that the problem becomes transformed from a small but difficult to solve problem into a big but relatively easy to solve problem. Through the process of discretizaton, a linear algebra problem is formed with perhaps tens of thousands of unknowns. However, algorithms exist that allow the resulting linear algebra problem to be solved, usually in a short amount of time $[13,14]$.

The simulation procedure using FEMM 4.2 in general contains following steps [15]:

1. Geometric modeling

Geometry of the generator is shaped into a quarter of segment or one quadrant of the $2 \mathrm{D}$-generator. This is because of the other parts of segments are symmetrical.

2. Material definition

The materials are required to be defined as input parameters in details of material types, specific heat capacity, and thermal conductivity as depicted in Table 2. the types of materials previously defined in Table 2 are then correlated to the accordingly segments as depicted in Figure 3. Frame made of aluminum is defined twice, i.e. for both the inner and outer parts. The winding is defined at every space. The same treatment is applied for all other types of materials at every accordingly segment.

3. Boundary condition determination

Thermal simulation process using FEMM 4.2 requires two boundary conditions, firstly is heat flux as the heat source produced by generator losses $\left(P_{\text {rot }}, P_{c u}\right.$ dan $\left.P_{\text {core }}\right)$, and secondly is convection boundary condition which is applied on the regions having contact with ambient temperature. The boundary conditions are shown in Figure 4 plotted with bold line.

4. Meshing (discreteness)

Meshing is defined as dividing the analyzed component into smaller elements [13]. The smaller the element, the more accurate result of simulation will be. The capability in defining the number of elements (meshing) is greatly influenced by the capability/specification of not only the computer but also the software in use. In this research, meshing process establishes 19560 nodes and 38670 elements as depicted in Figure 5.

5. The last stage is presenting the results.

Another boundary condition that is also required as an input parameter is the heat flux as source of heat generated from the computation of the total of losses in the generator. The second is boundary condition of the convection applied in the area or at the borders connected to ambient temperatures.

Thermal analysis on the generator is focused on 3 essential parts in accordance with endurance of the materials in receiving heat, i.e. magnet, winding, and frame.

\section{B. Experiment}

The observation on temperature rise is conducted on the frame and winding. Permanent magnet temperature is not able to be monitored due to its position at the rotating rotor that makes it very difficult to put a sensor on. A block diagram and the testing setup are displayed in Figure 6.

Main motor is the induction motor of $11 \mathrm{~kW}(\mathrm{M})$ in which its rotation is regulated by an oscillator. Generator $(\mathrm{G})$ is connected to the assigned load in form of water resistance. The test is executed within nominal conditions, i.e. load of $1200 \mathrm{~W}$ and rotation of $300 \mathrm{rpm}$. Temperature rises on the frame and winding are then recorded at every 30-minute interval for 7 hours. If the temperature has reached $120^{\circ} \mathrm{C}$ before 7 hours, the experiment will be interrupted to avoid magnet damage (allowable maximum temperature of magnet is $120^{\circ} \mathrm{C}$ ).

\section{RESUlts AND DisCUSSION}

The first stage to obtain temperature distribution is to calculate each loss and heat flux. Heat flux is obtained by dividing each loss with the boundary area in which the loss is generated. Boundary area (defined as BCs in Figure 7) consists of three parts, which are $\mathrm{BCs} 1$ for rotational loss, $\mathrm{BCs} 2$ for copper loss and $\mathrm{BCs} 3$ for core loss. $\mathrm{BCs} 1$ is equal to $\mathrm{A}_{1}, \mathrm{BCs} 2=\mathrm{A}_{2}$ and $\mathrm{BCs} 3=\mathrm{A}_{3}$. To calculate boundary area in each $\mathrm{BCs}$, these following equations are employed:

$A 1=2 \pi r_{1} l_{\text {stack }}$

$A 2=\left(2 h_{s}+b_{s}\right) l_{\text {stack }} . N s$

$A 3=2 \pi r_{3} l_{\text {stack }}$

where $r_{1}=0.115 \mathrm{~m}, r_{2}=0.073 \mathrm{~m}, h s=0.01967 \mathrm{~m}, b s=$ $0.00432 \mathrm{~m}, l_{\text {stack }}=0.103 \mathrm{~m}$ and $N \mathrm{~s}=$ number of stator slot $=54$.

Heat flux for every loss of $P_{r o t}, P_{c u}$ and $P_{c o r e}$ was determined using the area of each BCs (see Table 3). Computational results on the losses and heat flux are shown in Table 3.

Meanwhile the temperature distribution represented in a 2 - dimensions form for each generator segment is displayed in Figure 8. From the figure it can be seen that no heat concentration or hotspot exists. Every generator segment receives relatively the same temperature flow (evenly). As the whole, temperature variation takes place within the range of $3.122 \cdot 10^{2} \mathrm{~K}-3.223 \cdot 10^{2} \mathrm{~K}$ or $39.2^{\circ} \mathrm{C}$ $-49.3^{\circ} \mathrm{C}$ (as displayed in the data box).

The highest temperature exists at winding area as the area holds the biggest heat flux. Meanwhile the lowest temperature is found at the area of rotor shaft because this area contains convectional heat transfer mechanism at two areas, i.e. rotor and air gap.

To obtain more precisely estimated temperature values on three generator components, i.e. frame, winding, and permanent magnet, it is therefore a must to determine 
boundary conditions (Figure 9), which results in fluctuating temperatures that are illustrated in Figure 10. The $x$ axis is the length of boundary condition path, i.e. \pm $187.5 \mathrm{~mm}$ for frame, $16 \mathrm{~mm}$ for permanent magnet and \pm $6.4 \mathrm{~mm}$ for winding.

At a glance Figure 10 shows quite high differences among those three observed components. However when the display only shows the ranges of their minimum and maximum temperatures, the differences are in fact very slight, even they do not reach $0.1^{\circ} \mathrm{C}$ (Table 4). This also strengthens the prediction that no heat concentration occurs at one of the generator segments.

Results of analysis using finite element method are afterwards compared to the experiment results showing that the trend of temperature rises at the frame and winding as depicted in Figure 11.

The initial temperature at winding is $29^{\circ} \mathrm{C}$ and it linearly rises up to $59^{\circ} \mathrm{C}$ within 3.5 hours. The temperature then becomes stable at $62^{\circ} \mathrm{C}$ within the next 3.5 hours.

The increase of temperature at winding is caused by heat generated by copper losses, core losses, and rotational losses (Table 3). That heat causes resistance inside the winding to increase as it is stated in equation [16]:

$\mathrm{R}_{\mathrm{T} 2}=\mathrm{R}_{\mathrm{T} 1}\left(1+\alpha\left(\mathrm{T}_{2}-\mathrm{T}_{1}\right)\right)$

where, $R_{T 1}=$ the winding resistance at temperature $\mathrm{T}_{1}$, $R_{T 2}=$ the winding resistance at temperature $\mathrm{T}_{2}, \alpha=$ coefficient of the winding temperature, for copper $=$ $0.00393 \Omega /{ }^{\circ} \mathrm{C}$ at the temperature of $20^{\circ} \mathrm{C}$. In the case of $\mathrm{T} 2>\mathrm{T} 1$, winding resistance will rise. The rising resistance value affects to the rise of copper losses $\mathrm{I}^{2} \mathrm{R}$. This reciprocal relation between the temperature and resistance occurs continuously until the temperature reaches its stable point.

Winding temperature resulted from the experiment is higher compared to just $49.23^{\circ} \mathrm{C}$ resulted from the simulation. This happens because the increase factor of resistance value is not inclusively computed by software FEMM 4.2 or the simulation itself is conducted at a steady state condition.

The initial temperature of the frame is $28^{\circ} \mathrm{C}$ slightly lower than that of the winding because of the frame is directly connected to open air. The rise temperature pattern of the frame relatively has a slighter slope compared to that of the winding. The temperature rises during the first 2 hours until it becomes $52^{\circ} \mathrm{C}$. Afterwards, it remains stable at that point in the next 5 hours. The rise temperature of the frame is driven by conduction heat flow from the main source of heat (winding). In this matter, frame at the same time functions as a media of heat releaser from the generator to ambient. Similarly to that occurs at the winding, frame temperature resulted from the experiment is higher than that resulted from the simulation, in which its value is only $49.03^{\circ} \mathrm{C}$.

From the two observed segments, temperatures resulted from the simulation are found different from the experiment because the simulation is conducted using the approach of steady state analysis (time factor is excluded). Whilst data for the experiment includes the time function (dynamic). This fact also reveals the weakness of software FEMM 4.2. A thermal Study using force convection as the applied method of dynamic heat release (computational fluid dynamic) is recommended for further research as one of the efforts to achieve more optimal results.

\section{CONCLUSION}

The thermal analysis using finite element method with software FEMM 4.2 can display the details of temperature distribution on each observed segment. Even though the simulation is executed at a steady state condition. Whilst the experiment is at a dynamic situation, the prediction results of simulation are quite helpful in preventing the occurrence of overheating and hotspot in a generator.

\section{ACKNOWLEDGEMENT}

The authors are grateful to the Research Center of Telimek LIPI for its permission to publish this research. The authors also would like to thank all team members of electric machine research.

\section{REFERENCES}

[1] S. R. Trout, "For the electric manufacturing and coil winding conference", Cincinnati, Ohio, USA, 2001

[2] http://spontaneousmaterials.com/Papers/CoilWinding2001.pdf

[3] S. Inamura, T. Sakai, K. Sawa, "A temperature rise analysis of switched reluctance motor due to the core and copper loss by FEM", IEEE Transactions on Magnetics, Vol. 39, No. 3, pp. 155457, 2003.

[4] A. Boglietti, A. Cavagnino, D. Staton, M. Shanel, M. Mueller, C. Mejuto, "Evolution and Modern Approaches for Thermal Analysis of Electrical Machines", IEEE Transactions on Industrial Electronics, Vol. 56, No. 3, pp. 871-82, 2009.

[5] W.N.L.W. Mahadi, S.R. Adi, and K.M. Nor, "Thermal analysis of Neodymium Iron Boron $(\mathrm{NdFeB})$ magnet in the linear generator design", Proceedings of the Australasian Universities Power Engineering Conference, Brisbane, Australia, 2004.

[6] http://itee.uq.edu.au/ aupec/aupec04/papers/PaperID124.pdf.(acce ssed at 18/01/2010)

[7] K. Ohyama, M. Naguib, F. Nashed, K. Aso, H. Fujii, H. Uehara, "Design using finite element analysis of a switched reluctancemotor for electric vehicle", JPE, Vol. 6, No. 2, pp.163-71, 2006.

[8] Z. Xiaochen, L. Weili, C. Shukang, C. Junci, Z. Chunbo, "Therma analysis of solid rotor in PMSM used for EV" Proceedings of the Vehicle Power and Propulsion Conference, IEEE, 2009, pp. 163742 .

[9] G. Mahalingam, A. Keyhani, "Technical report”, Unpublished, Department of Electrical Engineering - The Ohio State University, 2000 .

[10] W. Wu, V. S. Ramsden, T. Crawford, and G. Hill, Proceeding of IEEE Industrial Appl. Conference, 2000, pp. 147.

[11] I. Boldea and A.N. Syed, "The induction machine handbook, electronic edition", CRC Press LLC, 2002.

[12] F. Sahin, "Design and Development of A High-Speed Axial-Flux Permanent-Magnet. Machine", Ph.D Thesis, Technisiche Universiteit Eindhoven, 2001.

[13] H.J. Leinhard, "A heat transfer text book $3^{\text {rd }}$ edition", Cambridge Massachusets: Phlogiston Press, 2003, pp. 695.

[14] F. Kreith and A. Prijono, "Prinsip-prinsip perpindahan panas edis ketiga", Surabaya :Erlangga, 1997, pp. 13

[15] S.S. Rao, "The finite element method in engineering", Elsevier Science and Technology Books, 2004, pp. 3.

[16] D.V. Hutton, "Fundamental of finite element analysis", The Mc Graw Hill Company, 2004, pp. 4. 


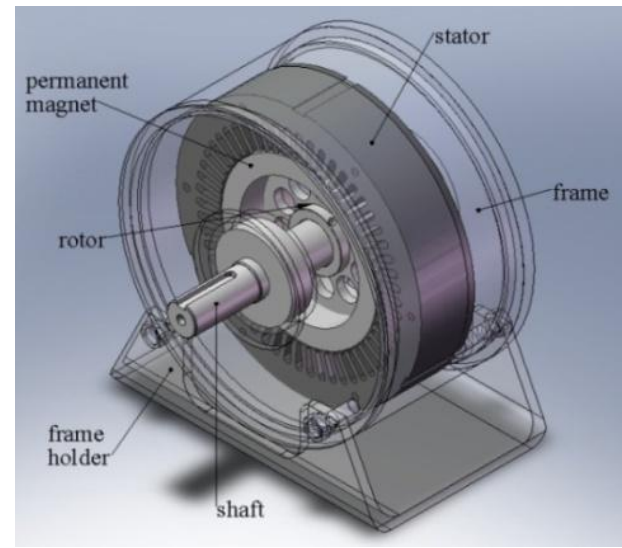

Figure 1. 3D profile of PMG prototype

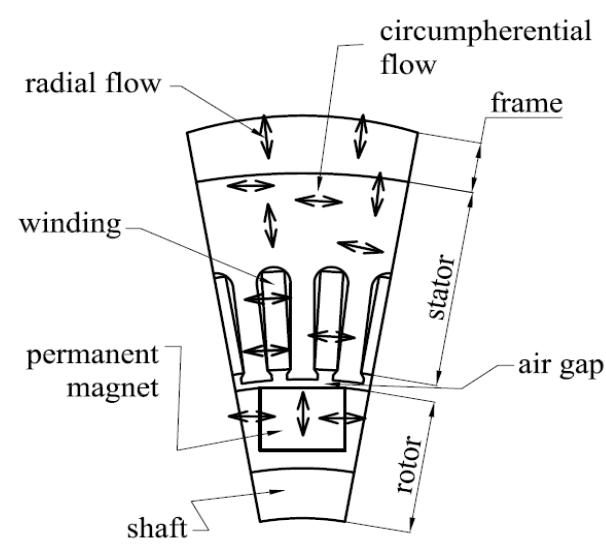

Figure 2. Heat transfer mechanism on generator

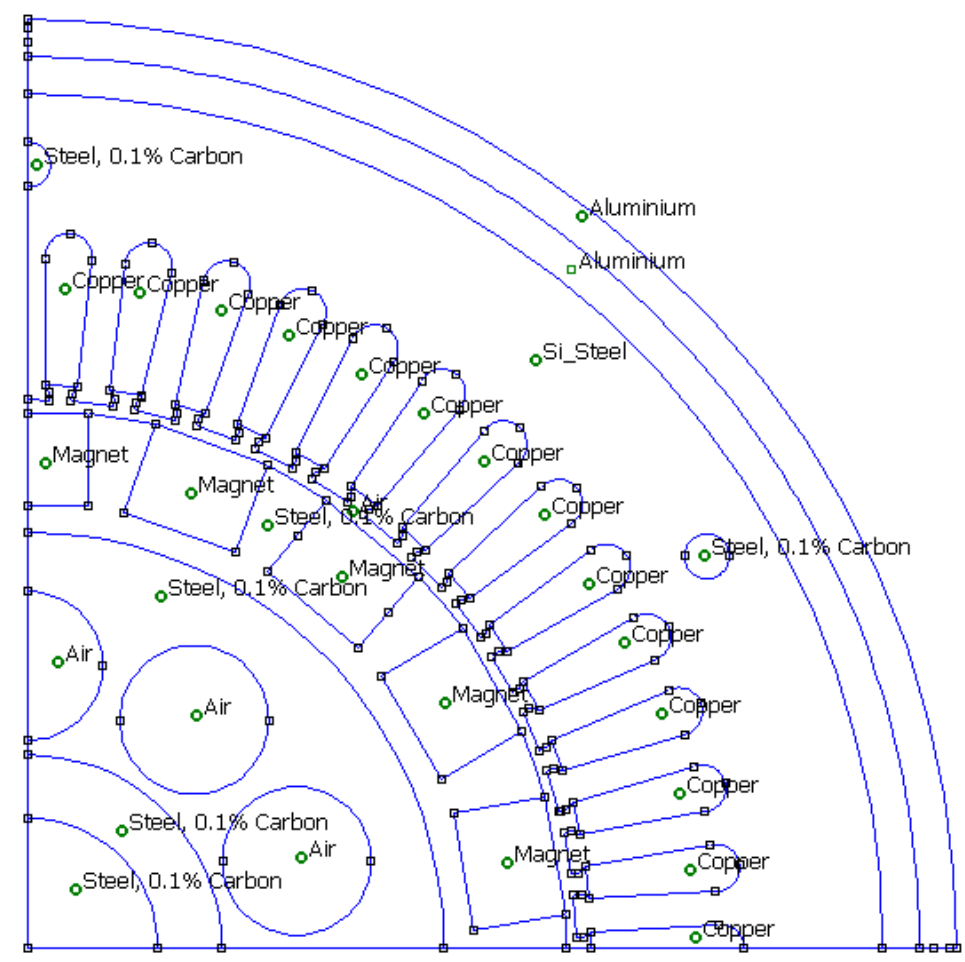

Figure 3. Definition of material boundary

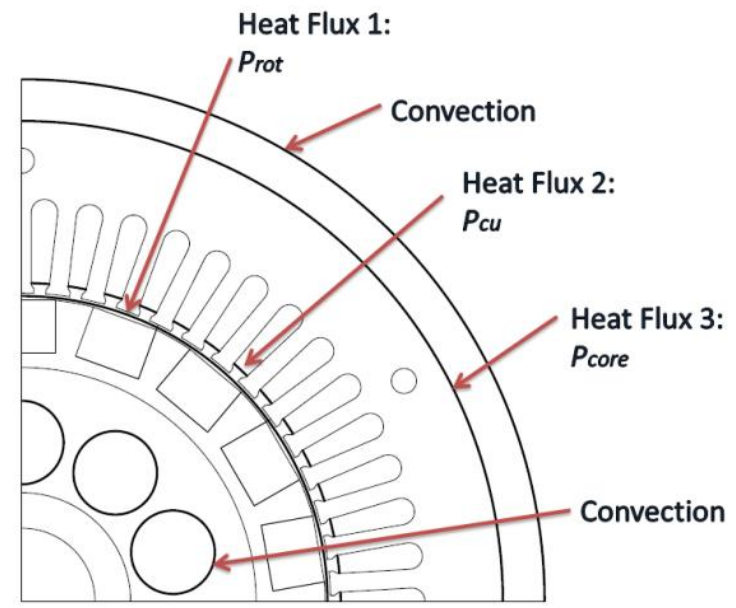

Figure 4. Definision of boundary condition 


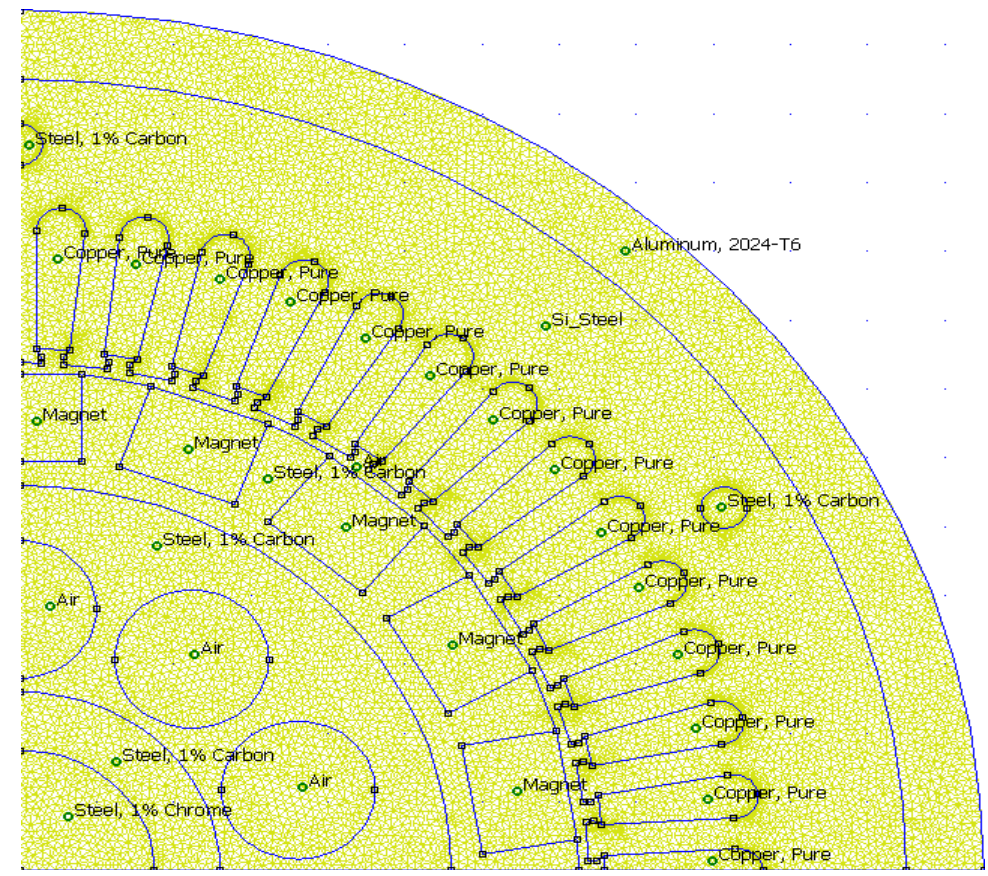

Figure 5. Result of meshing process

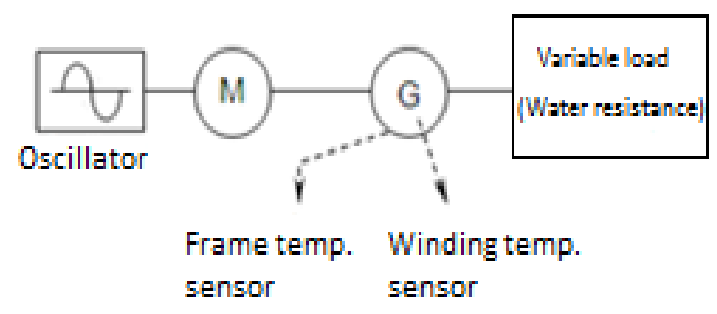

(a)

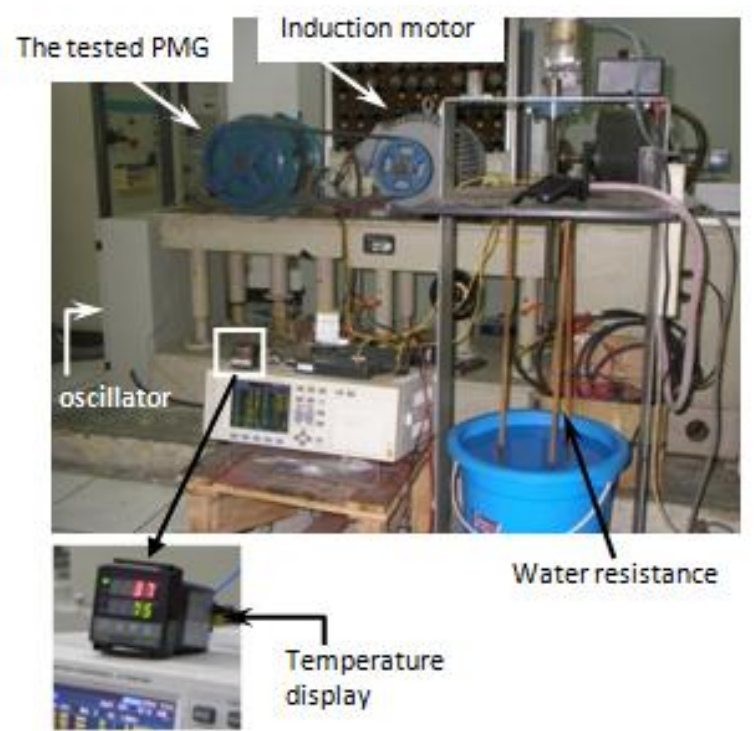

(b)

Figure 6. Experiment, (a) diagram block, (b) experimental set-up 


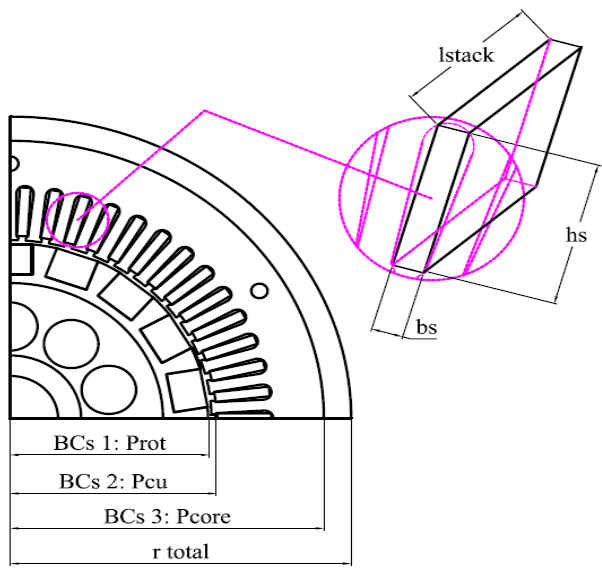

Figure 7. Dimension of boundary area at each BCs

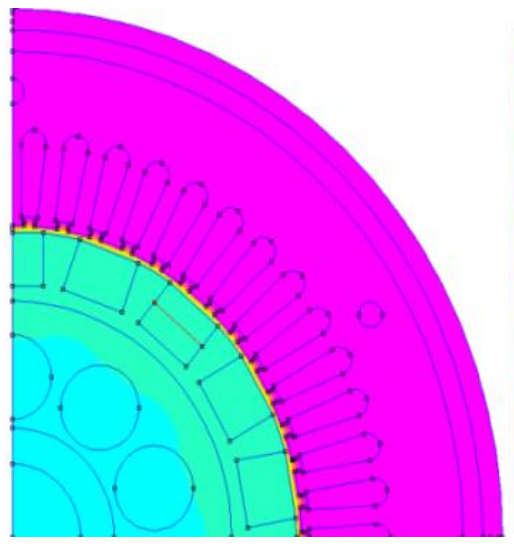

$3.218 \mathrm{e}+002:>3.223 \mathrm{e}+002$ $3.213 \mathrm{e}+002: 3.218 \mathrm{e}+002$ $3.208 \mathrm{e}+002: 3.213 \mathrm{e}+002$ $3.203 \mathrm{e}+002: 3.208 \mathrm{e}+002$ $3.198 \mathrm{e}+002: 3.203 \mathrm{e}+002$ $3.192 \mathrm{e}+002: 3.198 \mathrm{e}+002$ $3.187 \mathrm{e}+002: 3.192 \mathrm{e}+002$ $3.182 \mathrm{e}+002: 3.187 \mathrm{e}+002$ $3.177 \mathrm{e}+002: 3.182 \mathrm{e}+002$ $3.17 \mathrm{e}+002: 3.177 \mathrm{e}+002$ $3.167 \mathrm{e}+002: 3.172 \mathrm{e}+002$ $3.162 \mathrm{e}+002: 3.167 \mathrm{e}+002$ $3.157 \mathrm{e}+002: 3.162 \mathrm{e}+002$ $3.152 \mathrm{e}+002: 3.157 \mathrm{e}+002$ $3.147 \mathrm{e}+002: 3.152 \mathrm{e}+002$ $3.142 \mathrm{e}+002: 3.147 \mathrm{e}+002$ $3.137 \mathrm{e}+002: 3.142 \mathrm{e}+002$ $3.132 \mathrm{e}+002: 3.137 \mathrm{e}+002$ $3.127 \mathrm{e}+002: 3.132 \mathrm{e}+002$ $<.122 \mathrm{e}+002: 3.127 \mathrm{e}+002$

Figure 8. Temperature distribution at the generator displayed in 2dimension

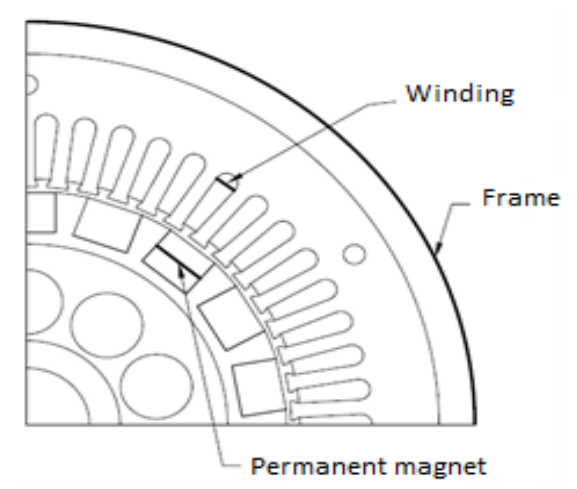

Figure 9. Focused area of analyzed thermal using FEMM 4.2

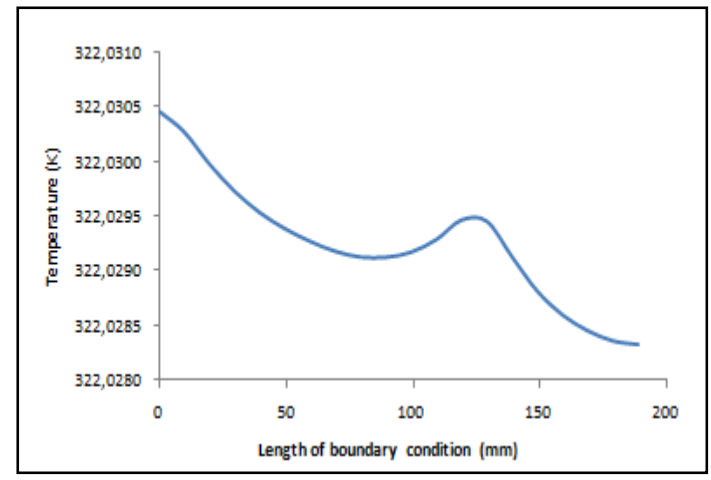

(a)

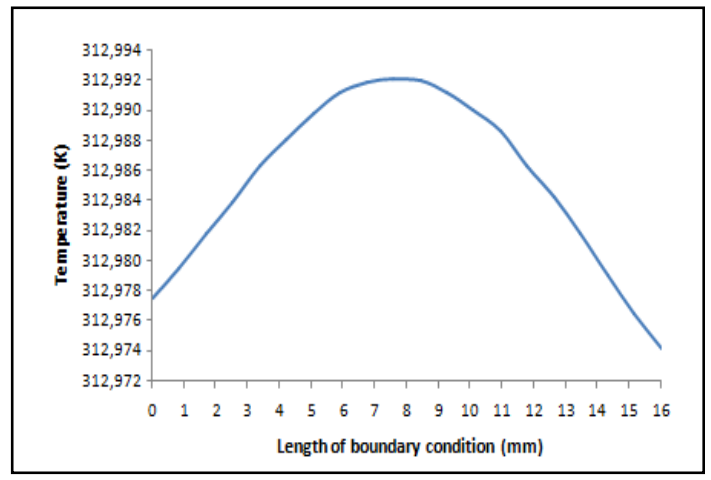

(b)

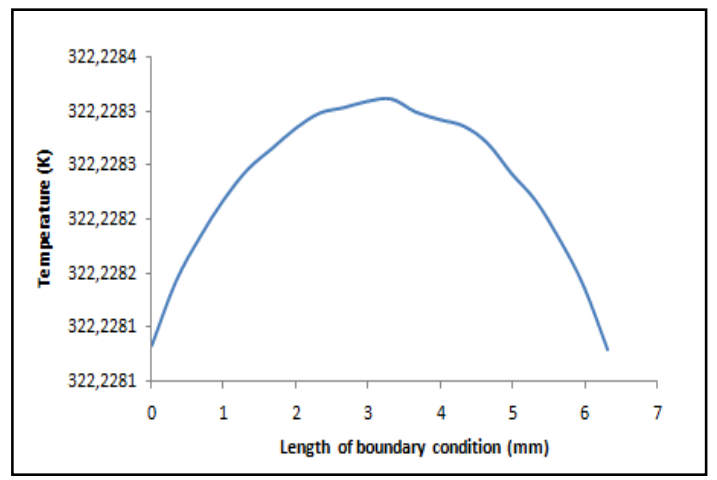

(c)

Figure 10. Results of simulation on temperature variation (a) frame, (b) permanent magnet, and (c) winding 


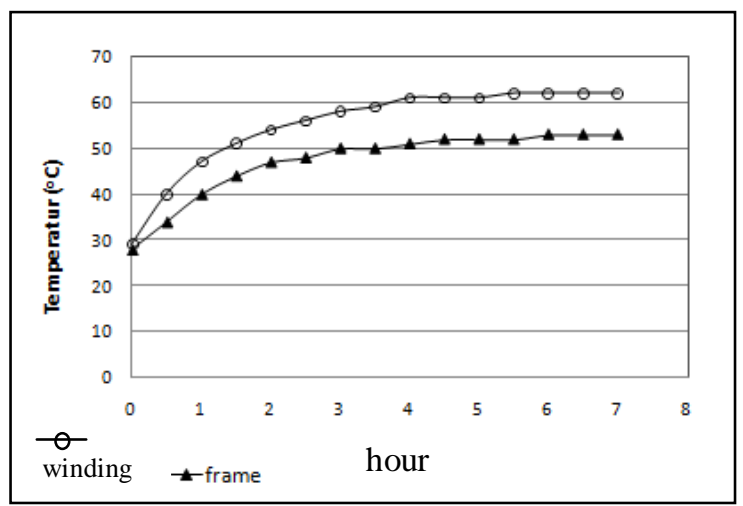

Figure 11. Experimental results on the rise of temperature in the frame and winding

TABLE 1.

PARAMETERS OF PMG DESIGN

\begin{tabular}{lcc} 
Parameter (unit) & Symbol & Volume \\
\hline Power (watt) & $P$ & 1200 \\
Nominal voltage (volt) & $E$ & $220 / 380$ \\
Nominal frequency & $f$ & 50 \\
Number of phase & $m$ & 3 \\
Magnet surface area $\left(\mathrm{m}^{2}\right)$ & $A_{\mathrm{m}}$ & $1.6 .10^{-3}$ \\
Nominal speed (rpm) & $n$ & 300 \\
Pole number & $p$ & 18 \\
Stator outer diameter $(\mathrm{m})$ & $D_{\mathrm{o}}$ & 0.34 \\
Stator inner diameter $(\mathrm{m})$ & $D_{\mathrm{i}}$ & 0.1476 \\
Rotor diameter $(\mathrm{m})$ & $D_{\mathrm{r}}$ & 0.147 \\
Number of slots & $S_{\mathrm{s}}$ & 54 \\
Winding per phase & $N_{\mathrm{ph}}$ & 576
\end{tabular}

TABLE 3.

COMPUTATIONAL RESULTS OF THE LOSSES AND HEAT FLUX

\begin{tabular}{lccc}
\hline \multicolumn{2}{c}{ Losses $(\mathrm{W})$} & $\begin{array}{c}\text { Boundary area } \\
\left(\mathrm{m}^{2}\right)\end{array}$ & $\begin{array}{c}\text { Heat flux } \\
\left(\mathrm{W} / \mathrm{m}^{2}\right)\end{array}$ \\
\hline$P_{\text {cu }}, \quad 146.48$ & 0.266865 & 548.89 \\
$P_{\text {core }}, \quad 7.77$ & 0.074424 & 104.45 \\
$P_{\text {rot }}, \quad 5$ & 0.047243 & 105.84 \\
\hline
\end{tabular}

TABLE 2.

MATERIAL CHARACTERISTICS OF GENERATOR

\begin{tabular}{lccc}
\hline \multicolumn{1}{c}{ Segment } & Material & 1 & 2 \\
\hline Permanent magnet & NdFeB & 3.11 & 9 \\
Stator & Silicon Steel & 3.77 & $20-30$ \\
Winding & Copper & 3.40 & 360 \\
Frame & Aluminum & 2.43 & 220 \\
Shaft and rotor & Steel, 1\% carbon & 3.53 & 52 \\
Ventilation hole & Air & 0.0012 & 0.025 \\
\hline
\end{tabular}

Notes : $1=$ Specific Heat Capacity $\left(\mathrm{MJ} / \mathrm{m}^{3} \mathrm{~K}\right)$

$2=$ Thermal Conductivity $(\mathrm{W} / \mathrm{mK})$

TABLE 4 .

RANGe OF TEMPERATURE ON Frame, PERMA-NENT MAGNET, AND WINDING

\begin{tabular}{|c|c|c|c|c|c|}
\hline \multicolumn{6}{|c|}{ WINDING } \\
\hline \multirow{3}{*}{ Segment } & \multicolumn{4}{|c|}{ Temperature } & \multirow{3}{*}{1} \\
\hline & \multicolumn{2}{|c|}{ Minimum } & \multicolumn{2}{|c|}{ Maximum } & \\
\hline & $\mathrm{K}$ & ${ }^{\circ} \mathrm{C}$ & $\mathrm{K}$ & ${ }^{\circ} \mathrm{C}$ & \\
\hline Frame & 322.03 & 49.02 & 322.03 & 49.03 & 0.01 \\
\hline Magnet & 312.99 & 39.99 & 312.97 & 39.97 & 0.02 \\
\hline Winding & 322.22 & 49.22 & 322.22 & 49.22 & 0.00 \\
\hline
\end{tabular}

Note: $1=$ Temperature Difference $\left({ }^{\circ} \mathrm{C}\right)$ 